\title{
A new status of the subgenus Parabruchopbagus Zerova, 1992 (Hymenoptera: Eurytomidae) and its composition
}

\author{
Новый статус подрода Parabruchophagus Zerova, 1992 \\ (Hymenoptera: Eurytomidae) и его состав
}

\begin{abstract}
M.D. Zerova
M.A. Зерова

I.I. Schmalhausen Institute of Zoology, National Academy of Sciences of Ukraine, 15 Bogdan Khmelnytsky str., Kiev 01601, Ukraine. E-mail: zerova@izan.kiev.ua

Институт зоологии им. И.И. Шмальгаузена Национальной Академии наук Украины, ул. Богдана Хмельницкого, 15, Киев 01601, Украина.
\end{abstract}

KEY WORDS: Hymenoptera, Eurytomidae, Parabruchophagus, new status, new species.

КЛЮЧЕВЫЕ СЛОВА: Нymenoptera, Eurytomidae, Parabruchophagus, новый статус, новые виды.

ABSTRACT. Status of the subgenus Parabruchophagus Zerova, 1992 of the genus Bruchophagus Ashmead, 1888 is raised to the genus level (stat.n.) on the basis of analysis of its morphological characters, trophic associations and distribution features. This genus includes five species; two of them are described here as new for the science (P. rasnitsyni sp.n. and P. kazakhstanicus sp.n.). All species of this genus are phytophagous; they develop inside the seeds of Eremurus species (Liliaceae).

РЕЗЮМЕ. На основании анализа особенностей морфологии, трофических связей и распространения видов подрода Parabruchophagus Zerova, 1992 рода Bruchophagus Ashmead, 1888 статус этого таксона повышен до родового уровня (stat.n.). Данный род включает пять видов, два из которых описаны в настоящей статье как новые для науки ( $P$. rasnitsyni sp.n. и P. kazakhstanicus sp.n.). Все виды рода - фитофаги в семенах лилейных рода Eremurus (Liliaceae).

\section{Introduction}

Three species of the genus Bruchophagus Ashmead, 1888, which larvae develop inside the seeds of Eremurus Marschall von Bieberstein, 1810 (Liliaceae), were described by the author of the present paper [Zerova, 1975]. Later on, those species were included into the subgenus Parabruchophagus Zerova, 1992 which was erected within the genus Bruchophagus [Zerova, 1992]. Specimens of another two new species that belong to Parabruchophagus were collected during the last few decades in the alpine regions of Afghanistan and Kazakhstan. I have considered the combination of morphological characters, trophic associations and distribution features of this subgenus as an enough good reason to raise its status up to the independent genus Parabruchophagus Zerova, 1992, stat.n. The morphological characters that distinguish species of Parabruchophagus from other Bruchophagus species are: (1) presence of the dense and dull sculpture on the head and dorsal surface of the mesosoma; (2) the sculpture mentioned above is formed by rather shallow foveae and minute plicae; (3) head and dorsal surface of the mesosoma with thick pubescence; (4) clearly marked postgenal carina in the lower lateral part of the cheek (in contrast to Bruchophagus); (5) all four flagellar segments of the male antenna are thin with short pubescence as in the female (the main distinctive character of Parabruchophagus species). The description of the genus and two new species together with a key to the species of Parabruchophagus are given below. Type material of new species is deposited in the collection of the Institute of Zoology, National Academy of Sciences of Ukraine (IZAN), Kiev, Ukraine.

\section{Taxonomic part}

Genus Parabruchophagus Zerova, 1992, stat.n. 1975.

Type species: Parabruchophagus tauricus Zerova,

DESCRIPTION. Female. Body black, without metallic reflection, head and dorsal surface of mesosoma with dense and dull sculpture; sculpture formed by rather shallow foveae and minute wrinkles. Head and mesosoma with dense but short pubescence. Head transverse in above view, somewhat broader than mesosoma. Head in frontal view distinctly wider than high, with relatively short genae, lower margin of clypeus weakly convex. Antennae inserted in middle of face, flagellum 5-segmented, club 3-segmented, pubescence very short and sparse. 


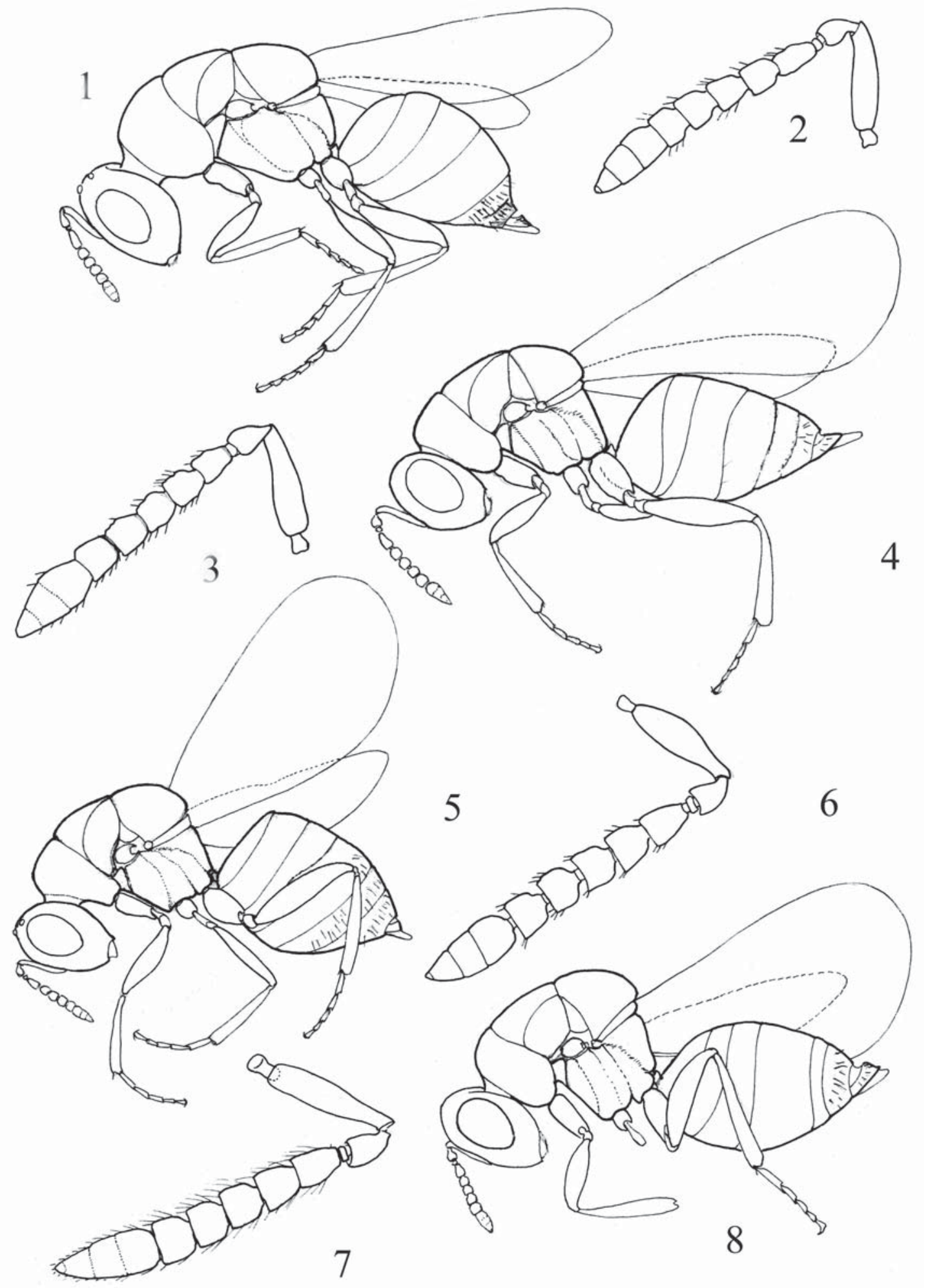

Figs 1-8. Details of morphology of Parabruchophagus species. 1,2-P. tauricus; 3, 4-P. nikolskaji; 5, 6-P. saxatilis; 7, $8-P$. rasnitsyni, sp.n. 1, 4, 5, 8 - female, lateral view; 2, 3, 6, 7 - female antenna.

Рис. 1-8. Особенности морфологии видов рода Parabruchophagus. 1,2-P. tauricus; $3,4-$ P. nikolskaji; 5, 6 - P. saxatilis; 7 , 8 - P. rasnitsyni, sp.n. $1,4,5,8$ - самка, вид сбоку; $2,3,6,7$ - усик самки. 
Mesosoma bulging, pronotum approximately two times broader than long; mesoscutum with distinct notauli. Propodeum inclined, median area with irregular and more or less longitudinal carinulae. All coxae with very fine punctation. Fore wing hyaline. Marginal vein short, postmarginal vein of different length.

Metasoma rounded, petiole very short.

Male. Similar in colour to female. Metasoma short and rounded, petiole as long as or slightly longer than hind coxae. Antennal funicle 4-segmented, segments of flagellum not convex, their shape and pubescence are similar to those of female. Scape of antenna slightly convex. Genitalia with closed phallobase.

BIOLOGY, DISTRIBUTION AND COMPOSITION. Larvae develop inside seeds of Eremurus species (Liliaceae). All species are associated with high mountain regions of Eurasia. Five species are included in this genus.

\section{Parabruchophagus rasnitsyni Zerova sp.n. Figs 7, 8, 16-18, 27, 28.}

MATERIAL. Holotype: female, Afghanistan, Bamian BandeAmir, h=1300m, 4.07.2009, leg. I. Pljushtch. Paratypes: one female and one male with same labels as holotype.

DESCRIPTION. Female. Body length 3.0-3.2 mm (3.0 $\mathrm{mm}$ in holotype). Body black; coxae black; femora black with yellow tips; tibiae black, yellow at base and apex; tarsi yellowish brown; tip of ovipositor alutaceous; antennae black; wings hyaline, veins yellow. Head and dorsal surface of mesosoma with dense dull sculpture and short sparse pubescence.

Head in above view twice as broad as long (63:30). Head in frontal view wider than high $(63: 48)$; cheek shorter than longitudinal diameter of eye (18:28); eyes bare; lower face without keels and wrinkles; lower margin of clypeus slightly protruding. Antennae inserted above middle of face; face cavity without lateral border; scape reaches mid ocellus, anellus very short, pedicel long (about 0.8 length of first flagellar segment), first flagellar segment longer than wide, second and third flagellar segments almost square, fourth and fifth segments somewhat shorter than second and third segments; funicular pubescence short, slightly visible.

Mesosoma somewhat bulging; pronotum in above view almost 3.0 times as wide as long; scutellum with more distinct wrinkles than pronotum and mesoscutum; mesopleuron with very fine reticulation. Propodeum inclined with fine punctation. All coxae with very fine punctation.

Metasoma rounded, somewhat longer than mesosoma in lateral view $(48: 38)$; apex of metasoma with sparse pubescence.

Male. Body length $2.3 \mathrm{~mm}$. Colour and sculpture as in female; all funicular segments elongate, first segment longer than second (17:13), all funicular segments with short pubescence. Petiole distinct, longer than hind coxae in lateral view.

COMPARATIVE REMARKS. The new species is similar to P. kazakhstanicus sp.n., but differs by hav- ing shorter postmarginal vein, somewhat longer cheeks and longer metasomal petiole in male.

ETYMOLOGY. The species is named after Prof. A.P. Rasnitsyn, a famous specialist on Hymenoptera, on his 75 th anniversary.

\section{Parabruchophagus kazakhstanicus Zerova, sp.n.} Figs 12, 20, 29, 30.

MATERIAL. Holotype: male, Kazakhstan, South Kazakhstan (= Shymkent) Province, $16 \mathrm{~km} \mathrm{~N} \mathrm{Kektau,} \mathrm{Karzhantan} \mathrm{mountain}$ range, $\mathrm{h}=1700 \mathrm{~m}, 6.06 .1994$, leg. M. Nesterov.

DESCRIPTION. Male. Body length $2.3 \mathrm{~mm}$. Body black; coxae black; femora black with yellow tips; fore and middle tibiae yellowish brown, infuscate at middle; hind tibiae dark, almost black; antennae black; mandibles yellow; wings hyaline, veins light yellow. Head and dorsal surface of mesosoma with fine wrinkles and sparse pubescence.

Head in dorsal view approximately twice as wide as long (55:25), head in frontal view wider than high (55:34); cheek twice shorter than longitudinal diameter of eye (12:23); lower margin of clypeus somewhat gibbous, lower face without vertical wrinkles. Antennae inserted in middle of face; face cavity without lateral borders; scape almost reaches mid ocellus, somewhat gibbous, distinctly longer than two previous funicular segments; all funicular segments distinctly longer than wide, with short and rather sparse pubescence.

Mesosoma. Centre of propodeum with very fine punctation.

Wing. Postmarginal vein approximately 1.5 times longer than radial vein.

Metasoma. Petiole about 1.5 times longer than hind coxa in lateral view; metasoma rounded in lateral view, obviously shorter than mesosoma.

Female unknown.

COMPARATIVE REMARKS. The new species is similar to $P$. rasnitsyni sp.n.; morphological differences between those species are shown after description of $P$. rasnitsyni sp.n.

ETYMOLOGY. The name of the new species is derived from the name of the country of origin.

\section{A KeY tO SPECIES OF PARABRUCHOPHAGUS}

1(4). Marginal vein much shorter than radial vein (Fig. 12).

2(3). Marginal vein 2.0 times shorter than postmarginal vein; first funicular segment of female not longer than second segment; apex of female metasoma with sparse pubescence; male petiole 1.5 times longer than wide. From seeds of Eremurus robustus Regel and E. regelii Vvedensky (Figs 3, 4, 12, 13, 23, 24).

P. nikolskaji Zerova, 1975

3(2). Marginal vein 1.5 times shorter than postmarginal vein; first funicular segment in female 1.3 times longer than second segment; apex of female metasoma with dense pubescence; male petiole hardly longer than wide. From seeds of Eremurus olgae Regel .

$$
\text { P. saxatilis Zerova, } 1975
$$

4(1). Marginal vein as long as radial vein, sometimes hardly shorter (Fig. 9). 

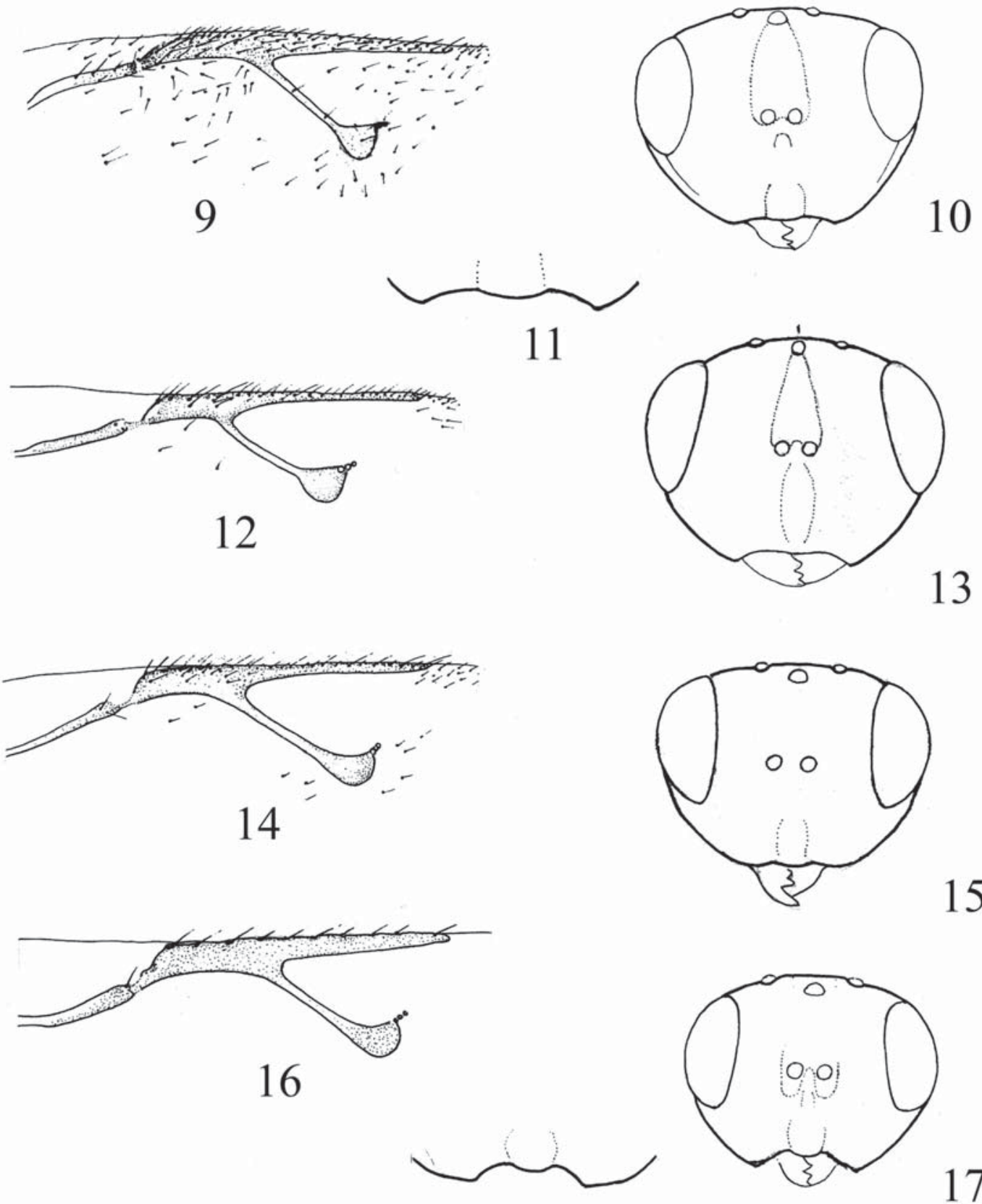

18

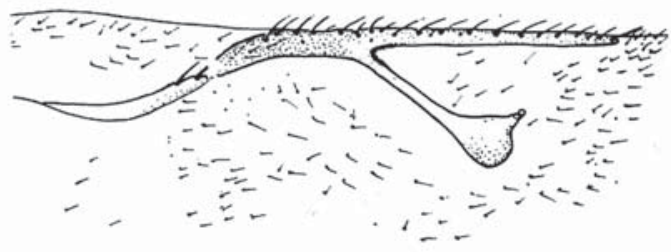

19

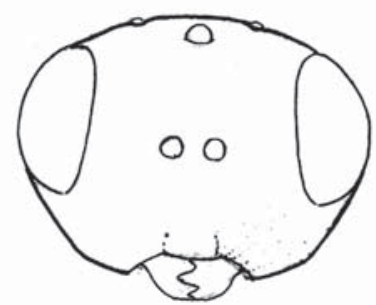

Figs 9-20. Details of morphology of Parabruchophagus species. 9-11-P. tauricus; $12,13-$ P. nikolskaji; $14,15-$ P. saxatilis; 16-18 - P. rasnitsyni, sp.n.; 19, 20 - P. kazakhstanicus, sp.n.; 9, 12, 14, 16, 19 - veins of forewing; 10, 13, 15, 17, 20 - head, frontal view; 11,18 - lower margin of clypeus.

Рис. 9-20. Особенности морфологии видов рода Parabruchophagus. 9-11 - P. tauricus; 12, $13-$ P. nikolskaji; 14, $15-P$. saxatilis; 16-18 - P. rasnitsyni, sp.n.; 19, 20 - P. kazakhstanicus, sp.n.; 9, 12, 14, 16, 19 - жилкование передних крыльев; 10, 13, $15,17,20$ - голова спереди; 11,18 - нижний край наличника. 


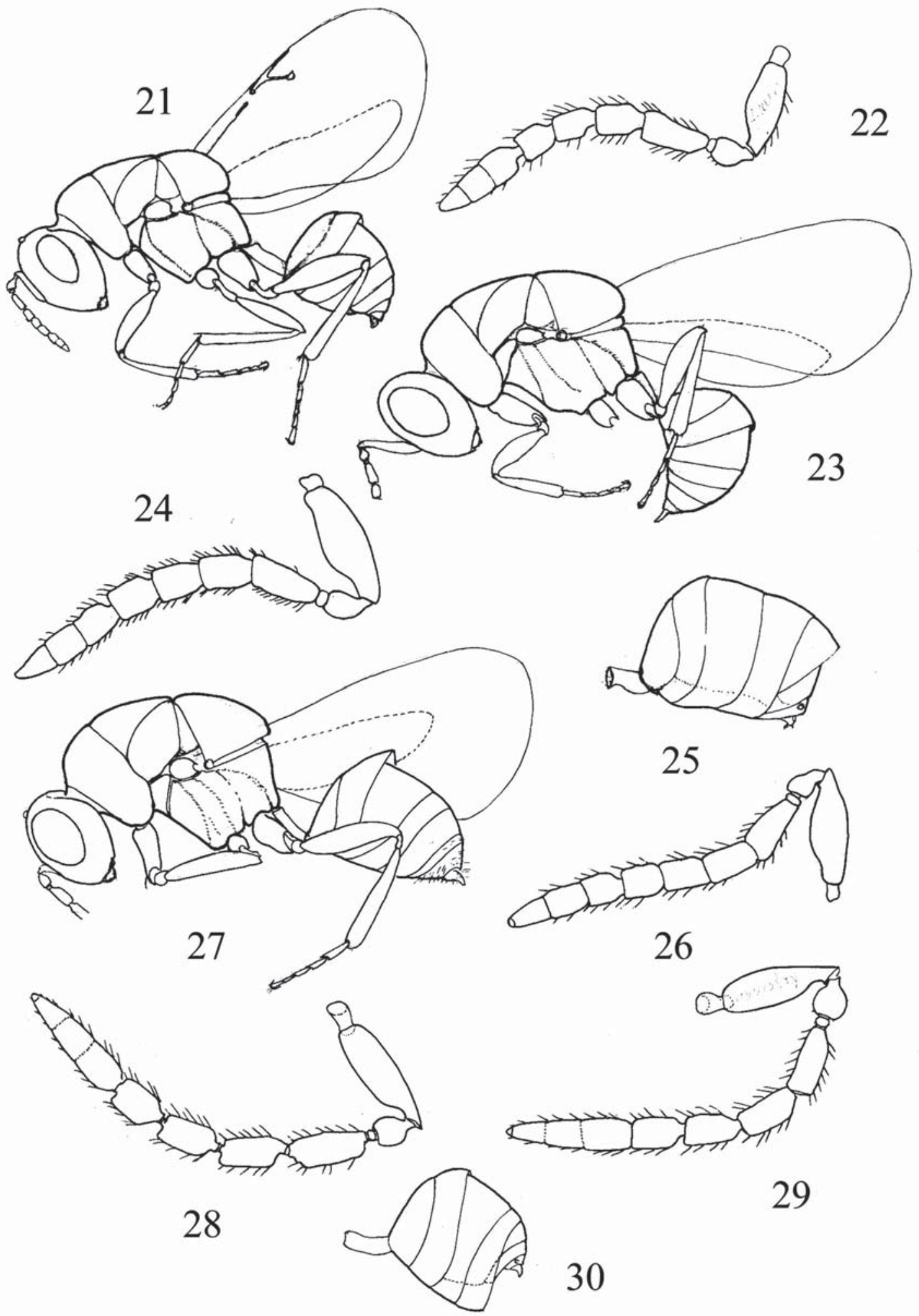

Figs 21-30. Details of morphology of Parabruchophagus species. 21, 22-P. tauricus; 23, 24-P. nikolskaji; 25, 26 - P. saxatilis; 27, 28 - P. rasnitsyni sp.n.; 29, 30 - P. kazakhstanicus, sp.n.; 21, 23, 27 - male, lateral view; 22, 24, 26, 28,29 - male antenna; 25, 30 - male metasoma.

Рис. 21-30. Особенности морфологии видов рода Parabruchophagus. $21,22-$ P. tauricus; 23, $24-$ P. nikolskaji; $25,26-P$. saxatilis; 27, 28 - P. rasnitsyni sp.n.; 29, 30 - P. kazakhstanicus, sp.n.; 21, 23, 27 - самец, вид сбоку; 22, 24, 26, 28, 29 - усик самца; 25,30 - брюшко самца. 
5(8). Postmarginal vein not less than 1.5 times longer than radial vein.

6(7). Cheek hardly shorter than longitudinal diameter of eye; third funicular segment of male slightly elongate, fourth segment almost square. - Apex of female metasoma with distinct dense pubescence. From seeds of Eremurus tauricus Steven (Figs 1, 2, 9-11, 21, 22)

P. tauricus Zerova, 1975

7(6). Cheek distinctly shorter than longitudinal diameter of eye; $3 \mathrm{rd}$ and 4 th funicular segments of male obviously longer than wide (Figs 19, 20, 29, 30)

P. kazakhstanicus sp.n.

8(5). Postmarginal vein slightly longer than radial vein. Apex of female metasoma with sparse pubescence. Fourth and fifth funicular segments in female distinctly square. All funicular segments of male obviously longer than wide (Figs 7, 8, 16-18, 27, 28) P. rasnitsyni sp.n.

\section{References}

Zerova M.D. 1975. [New species of seed-feeding chalcids of the genus Bruchophagus Ashm. (Hymenoptera, Eurytomidae) developing in Eremurus spp. Seeds] // Vestnik zoologii. No.6. P.41-45 [in Russian with English summary].

Zerova M.D. 1992. [New species of the genus Bruchophagus (Hymenoptera, Eurytomidae) with taxonomic analysis] // Vestnik zoologii. No.5. P.21-28 [in Russian with English summary]. 